\title{
PENGARUH PENGALAMAN PRAKTIK KERJA INDUSTRI DAN MOTIVASI TERHADAP KESIAPAN KERJA SISWA KELAS XII PROGRAM KEAHLIAN TEKNIK KOMPUTER DAN JARINGAN SMK TELKOM KENDARI
}

\author{
Oleh: \\ Arfin Bagea \\ Sekolah Tinggi Ilmu Ekonomi Enam Enam (STIE-66) Kendari \\ Email: arfin.bagea@yahoo.co.id
}

\begin{abstract}
Abstrak: Perkembangan IPTEK menuntut pembinaan sumber daya manusia yang berkualitas. Daya saing Indonesia dalam menghadapi persaingan antar negara maupun perdagangan bebas sangat ditentukan oleh outcome dari pembinaan sumber daya manusianya. Salah satu upaya negara dalam pemenuhan sumber daya manusia level menengah yang berkualitas adalah pembinaan pendidikan Sekolah Menengah Kejuruan. Penelitian ini bertujuan (1) untuk mengetahui pengaruh pengalaman praktik kerja industri terhadap Kesiapan Kerja Siswa, (2) untuk mengetahui pengaruh Motivasi terhadap Kesiapan Kerja Siswa, dan (3) untuk mengetahui pengaruh pengalaman praktik kerja industri dan motivasi kerja dan kesiapan kerja Siswa. Populasi dalam penelitian ini adalah seluruh siswa kelas XII Program Keahlian Teknik Komputer dan Jaringan SMK Telkom Kendari yang berjumlah 91 orang. Teknik Analisis data yang digunakan adalah analisis regresi berganda. Hasil Penelitian ini menunjukkan bahwa (1) peningkatan pengalaman praktik kerja industri (prakerin) dan motivasi berpengaruh positif dan signifikan terhadap kesiapan kerja siswa SMK Telkom Kendari. (2) pengalaman praktik kerja industri (prakerin) berpengaruh positif dan signifikan terhadap kesiapan kerja siswa kelas XII SMK Telkom Kendari. (3) motivasi berpengaruh positif dan signifikan terhadap kesiapan kerja, menemukan bahwa semakin baik motivasi dalam lingkup SMK Telkom Kendari, maka kesiapan kerja juga akan semakin baik.
\end{abstract}

\section{Kata Kunci : Pengalaman Prakerin, Motivasi, Kesiapan Kerja}

\section{PENDAHULUAN}

Perkembangan IPTEK menuntut pembinaan sumber daya manusia yang berkualitas. Daya saing Indonesia dalam menghadapi persaingan antar negara maupun perdagangan bebas sangat ditentukan oleh outcome dari pembinaan sumber daya manusianya. Salah satu upaya negara dalam pemenuhan sumber daya manusia level menengah yang berkualitas adalah pembinaan pendidikan sekolah menengah kejuruan (SMK). Menurut Rupert Evans (1978), pendidikan kejuruan adalah bagian dari sistem pendidikan yang mempersiapkan seseorang agar lebih mampu bekerja pada satu kelompok pekerjaan atau satu bidang pekerjaan daripada bidang-bidang pekerjaan lainnya. Menurut penjelasan Undang-Undang Nomor 20 Tahun 2003 Pasal 15, pendidikan kejuruan merupakan pendidikan menengah yang mempersiapkan peserta didik terutama untuk bekerja dalam bidang tertentu (Depdiknas 2006: 8). 
Sekolah Menengah Kejuruan (SMK) adalah menurut Schippers (1994:19) pendidikan kejuruan tingkat dasar yang berorientasi pada praktik dalam bidang-bidang pertukangan, kesehatan, bisnis, industry, pertanian, transportasi, pelayanan jasa, kesehatan, teknik, perkapalan, teknologi, dan lain sebagainya. Sementara itu, menurut Undang-Undang No. 2 tentang Sistem Pendidikan Nasional bahwasanya pendidikan kejuruan merupakan pendidikan yang mempersiapkan peserta didik untuk dapat bekerja dalam bidang tertentu dan mempersiapkan peserta didiknya untuk memasuki lapangan kerja.

Berdasarkan dari kedua konsep SMK tersebut, maka dapat disimpulkan bahwa SMK adalah pendidikan yang mempersiapkan peserta didik sebagai calon tenaga kerja dan mengembangka eksistensi peserta didik, untuk kepentingan peserta didik, masyarakat, bangsa dan Negara sesuai dengan jurusan atau keterampilan yang dipilihnya.

Untuk menunjang tujuan tersebut, dirancang Pendidikan Sistem Ganda (PSG), sebagai perwujudan kebijaksanan dan Link and Match. Dalam prosesnya, PSG dilaksanakan pada lembaga yaitu di sekolah dan di dunia kerja. Upaya ini dilakukan dalam rangka meningkatkan mutu tamatan SMK dalam menciptakan relevansi pendidikan dengan tuntutan kebutuhan tenaga kerja (Wena, 2009 : 15).

\section{Konsep Pengalaman Praktik Kerja Industri}

Wardiman Djojonegoro (2007:79) mengemukakan bahwa praktik Kerja industri adalah bentuk penyelenggaraan pendidikan keahlian kejuruan yang memadukan secara sistematik dan sinkron program pendidikan di sekolah dan program penguasan keahlian yang diperoleh melalui bekerja langsung di dunia usaha atau dunia industri (DU/DI), secara terarah untuk mencapai suatu tingkat keahlian profesional.

Praktik kerja industri adalah "suatu program yang bersifat wajib tempuh bagi siswa SMK yang merupakan bagian dari Program Pendidikan Sistem Ganda (PSG) dalam pedoman teknis pelaksanaan Pendidikan Sistem Ganda pada SMK disebutkan bahwa Praktik Kerja Industri adalah praktik keahlian produktif yang dilaksanakan di industri atau di perusahan yang berbentuk kegiatan mengajarkan pekerjan produksi dan jasa" (Kepmendiknas, 1997).

\section{Motivasi}

Siagian (2003:138) mengatakan bahwa motivasi adalah daya pendorong yang mengakibatkan seorang anggota organisasi mau dan rela untuk menggerahkan kemampuan dalam bentuk keahlian atau keterampilan, tenaga dan waktunya untuk menyelenggarakan berbagai kegiatan yang menjadi tanggung jawabnya dan melaksanakan kewajibannya, dalam rangka pencapaian tujuan dan berbagai sasaran organisasi yang telah ditentukan sebelumnya. Senada dengan definisi tersebut, Martin Handoko (1992:9) mengatakan motivasi juga bisa diartikan sebagai suatu tenaga atau faktor yang terdapat di dalam diri manusia, yang menimbulkan, mengarahkan dan mengorganisasikan tingkah lakunya. Di samping itu, Grifin (2003:38) mengemukakan bahwa motivasi adalah sekelompok faktor yang menyebabkan individu berperilaku dalam cara-cara tertentu, di mana motivasi merujuk pada kekuatan-kekuatan internal dan eksternal seseorang yang 
membangkitkan antusiasme dan perlawanan untuk melakukan serangkaian tindakan tertentu.

\section{Fungsi Motivasi Kerja} berikut:

Menurut Ngalim Purwanto (1998: 70) fungsi dari motivasi adalah sebagai

1. Motivasi itu mendorong manusia untuk berbuat/bertindak. Motif itu berfungsi sebagai penggerak atau sebagai motor yang memberikan energi (kekuatan) kepada seseorang untuk melakukan suatu tugas.

2. Motivasi itu menentukan arah perbuatan, yakni ke arah perwujudan suatu tujuan atau cita-cita. Motivasi mencegah pernyelewengan dari jalan yang harus ditempuh untuk mencapai tujuan itu. Makin jelas tujuan itu, makin jelas pula terbentang jalan yang harus ditempuh.

3. Motivasi itu menyeleksi perbuatan kita. Artinya menentukan perbuatanperbuatan mana yang harus dilakukan.

\section{Kesiapan Kerja}

Menurut Dalyono (2005: 52) "Kesiapan adalah kemampuan yang cukup baik fisik dan mental. Kesiapan fisik berarti tenaga yang cukup dan kesehatan yang baik, sementara kesiapan mental, memiliki minat dan motivasi yang cukup untuk melakukan suatu kegiatan", sedangkan menurut Oemar Hamalik (2008:94) "kesiapan adalah tingkatan atau keadaaan yang harus dicapai dalam proses perkembangan perorangan pada tingkatan pertumbuhan mental, fisik, sosial dan emosional".

Menurut Kamus Besar Bahasa Indonesia (2005: 554), "kerja diartikan sebagai kegiatan untuk melakukan sesuatu yang dilakukan atau diperbuat dan sesuatu yang dilakukan untuk mencari nafkah, mata pencaharian". Sependapat dengan Moh. Thayeb (1998: 27) "kerja diartikan sebagai suatu kelompok aktivitas, tugas, atau kewajiban yang sama dan dibayar, yang memerlukan atribut-atribut yang sama dalam suatu organisasi tertentu".

\section{Faktor-faktor yang Mempengaruhi Kesiapan Kerja}

Menurut Slameto (2010: 113), faktor-faktor yang mempengaruhi kesiapan mencakup tiga aspek, yaitu: (1) Kondisi fisik, mental dan emosional, (2) Kebutuhan-kebutuhan, motif dan tujuan, (3) Keterampilan, pengetahuan dan pengertian lain yang telah dipelajari. Ketiga aspek tersebut akan mempengaruhi kesiapan seseorang untuk berbuat sesuatu.

Kartini (1991: 21), mengemukakan bahwa faktor-faktor yang mempengaruhi Kesiapan Kerja adalah faktor-faktor dari dalam diri sendiri (intern) dan faktor-faktor dari luar diri sendiri (ekstern). Faktor-faktor dari dalam diri sendiri meliputi, kecerdasan, ketrampilan dan kecakapan, bakat, kemampuan dan minat, motivasi, kesehatan, kebutuhan psikologis, kepribadian, cita-cita, dan tujuan dalam bekerja, sedangkan faktor-faktor dari luar diri sendiri meliputi, lingkungan keluarga (rumah), lingkungan dunia kerja, rasa aman dalam pekerjaannya, kesempatan mendapatkan kemajuan, rekan sekerja, hubungan dengan pimpinan, dan gaji. Sejalan yang dikemukakan oleh Herminanto (1986: 6) "faktor yang 
mempengaruhi kesiapan mental kerja adalah prestasi belajar, keadaan ekonomi orang tua, bimbingan sosial, bimbingan karier, dan pengalaman kerja siswa".

\section{KERANGKA KONSEPTUAL DAN HIPOTESIS PENELITIAN Kerangka Konseptual}

Agar penelitian ini lebih terarah sesuai dengan rumusan masalah dan tujuan penelitian yang ingin dicapai, maka kerangka konseptual dibangun dengan tahapan sebagai berikut.

1. Pengaruh pengalaman praktik kerja industri terhadap kesiapan kerja

Pengalaman praktik kerja industri adalah pengetahuan atau keterampilan yang diketahui dan dikuasai peserta didik setelah mengikuti praktik kerja di dunia usaha atau dunia industri selama jangka waktu tertentu. Peserta didik dikatakan berpengalaman apabila telah memiliki tingkat penguasaan pengetahuan dan keterampilan yang relevan dan memadai sesuai dengan bidang keahliannya.

2. Pengaruh motivasi terhadap kesiapan kerja

Motivasi adalah sesuatu yang menimbulkan semangat atau dorongan peserta didik untuk memasuki dunia kerja. Baik berasal dari dalam diri sendiri maupun dari luar dirinya. Motivasi Memasuki Dunia Kerja berperan dalam membentuk Kesiapan Kerja.

3. Pengaruh Pengalaman Praktik kerja industri dan Motivasi Berpengaruh Secara Simultan Terhadap Kesiapan Kerja.

Kesiapan Kerja adalah keseluruhan kondisi individu yang meliputi kematangan fisik, mental dan pengalaman serta adanya kemauan dan kemampuan untuk melaksanakan suatu pekerjaan atau kegiatan. Kesiapan Kerja sangat penting dimiliki oleh seorang peserta didik SMK, karena peserta didik SMK merupakan harapan masyarakat untuk menjadi lulusan SMK yang mempunyai kompetensi sesuai dengan bidang keahliannya diterima di dunia kerja atau mampu mengembangkan melalui wirausaha.

Selanjutnya, pengaruh pengalaman Praktik kerja industri dan motivasi terhadap kesiapan kerja di atas dapat dilihat dalam kerangka konseptual penelitian berikut ini.

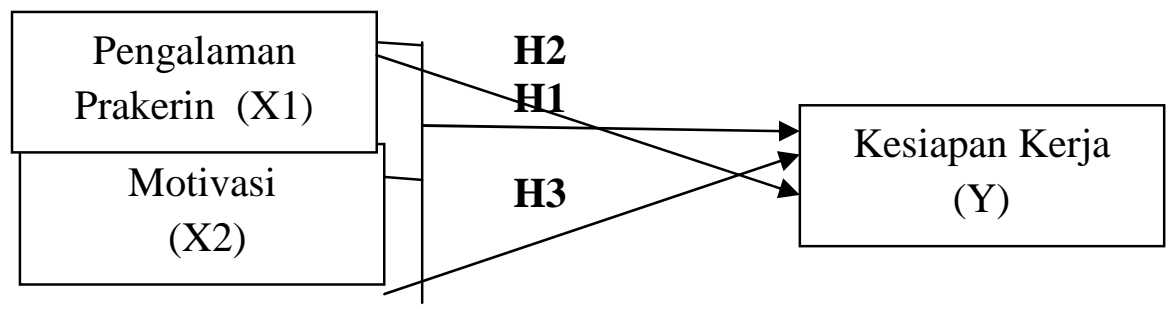

\section{METODE PENELITIAN}

\section{Obyek Penelitian}

Objek penelitian adalah pengaruh pengalaman praktik kerja industri dan motivasi terhadap kesiapan kerja siswa kelas XII Program Keahlian Teknik Komputer dan Jaringan SMK Telkom Kendari. 


\section{Jenis dan Sumber Data}

Adapun jenis data yang digunakan dalam penelitian ini adalah:

\section{a. Data Kualitatif}

Yaitu data yang bukan dalam bentuk angka-angka atau dalam bentuk informasi baik secara lisan maupun tertulis, dan diperoleh dari hasil wawancara dengan Kepala Sekolah, Guru dan Staf Administrasi Sekolah serta informasiinformasi yang diperoleh dari pihak lain yang berkaitan dengan masalah yang diteliti.

\section{b. Data Kuantitatif}

Yaitu data yang diperoleh dalam bentuk angka-angka yang dapat dihitung, yang diperoleh dari kuesioner yang dibagikan dan berhubungan dengan masalah yang diteliti.

\section{Populasi Penelitian}

Populasi adalah wilayah generalisasi yang terdiri atas: obyek atau subyek yang mempunyai kualitas dan karakteristik tertentu yang ditetapkan oleh peneliti untuk dipelajari dan kemudian ditarik kesimpulannya (Sugiyono, 2008: 80). Populasi dalam penelitian ini adalah seluruh peserta didik kelasm XII Program Keahlian Teknik Komputer dan jaringan SMK Telkom Kendari yang berjumlah 91 peserta didik. Kelas XII Program Keahlian Teknik Komputer dan Jaringan terdiri dari 3 kelas, yaitu XII TKJ1 dengan jumlah peserta didik 31, XII TKJ2 dengan jumlah peserta didik 30, dan XII TKJ3 dengan jumlah peserta didik 30. Oleh karena itu, penelitian ini merupakan penelitian populasi, maka dalam penelitian ini tidak menggunakan sampel, melainkan populasi akan digunakan dalam penelitian. Dari jumlah 91 peserta didik tersebut semuanya diambil sebagai responden penelitian.

\section{HASIL PENELITIAN DAN PEMBAHASAN \\ Deskripsi Variabel Penelitian}

Penelitian ini terdiri dari 3 (tiga) variabel yakni variabel pengalaman praktik kerja (X1), motivasi (X2) dan kesiapan kerja (Y1), penjelasan secara rinci hasil tabulasi data deskripsi responden sebagai berikut :

\section{Deskripsi Variabel Pengalaman Kerja Praktik Industri (X1)}

Pengalaman Prakerin adalah pengetahuan dan keterampilan yang diketahui, serta dapat dikuasai peserta didik setelah mengikuti praktik kerja di dunia industri selama jangka waktu tertentu. Pengalaman prakerin dicerminkan melalui : (a) Kemampuan hasil belajar, (b) Pengenalan lingkungan, (c) Pembentukan sikap, dan (d) Tingkat penguasaan pengetahuan yang sesuai dengan bidang keahliannya.

Hasil deskripsi variabel pengalaman praktik kerja industri dapat dilihat pada tabel 5.1. berikut : 
Tabel 5.1. Deskripsi Responden Variabel Pengalaman Praktek Kerja Industri

\begin{tabular}{|c|c|c|c|c|c|c|c|c|c|c|c|c|c|}
\hline \multirow{3}{*}{$\begin{array}{l}\text { Indikator } \\
\text { Variabel }\end{array}$} & \multirow{3}{*}{ Item } & \multicolumn{10}{|c|}{ Frekwensi (f) dan Persentase (\%) } & \multirow{2}{*}{\multicolumn{2}{|c|}{$\begin{array}{l}\text { Rerata } \\
\text { (Mean) }\end{array}$}} \\
\hline & & \multicolumn{2}{|c|}{ STS (1) } & \multicolumn{2}{|c|}{$\mathrm{TS}(2)$} & \multicolumn{2}{|c|}{$\mathrm{N}(3)$} & \multicolumn{2}{|c|}{ S (4) } & \multicolumn{2}{|c|}{ SS (5) } & & \\
\hline & & $\mathrm{F}$ & $\%$ & $\mathrm{~F}$ & $\%$ & $\mathrm{~F}$ & $\%$ & $\mathrm{~F}$ & $\%$ & $\mathrm{~F}$ & $\%$ & Item & in \\
\hline \multirow{3}{*}{$\begin{array}{l}\text { Pemantapan } \\
\text { Hasil Belajar } \\
\text { (X11) }\end{array}$} & $\mathrm{P} 1$ & 0 & $0,0 \%$ & 0 & $0,0 \%$ & 4 & $4,4 \%$ & 22 & $5,5 \%$ & 65 & $71,4 \%$ & 4,67 & \multirow{3}{*}{$\begin{array}{l}4, \\
29\end{array}$} \\
\hline & $\mathrm{P} 2$ & 0 & $0,0 \%$ & 2 & $2,2 \%$ & 5 & $5,5 \%$ & 67 & $16,8 \%$ & 17 & $18,7 \%$ & 4,09 & \\
\hline & P3 & 0 & $0,0 \%$ & 0 & $0,0 \%$ & 25 & $27,5 \%$ & 32 & $35,2 \%$ & 34 & $37,4 \%$ & 4,10 & \\
\hline \multirow{3}{*}{$\begin{array}{c}\text { Pengenalan } \\
\text { Lingkungan } \\
\text { (X12) }\end{array}$} & $\mathrm{P} 4$ & 0 & $0,0 \%$ & 0 & $0,0 \%$ & 21 & $23,1 \%$ & 39 & $42,9 \%$ & 31 & $34,1 \%$ & 4,11 & \multirow{2}{*}{$\begin{array}{l}4, \\
08\end{array}$} \\
\hline & P5 & 0 & $0,0 \%$ & 0 & $0,0 \%$ & 7 & $7,7 \%$ & 72 & $79,1 \%$ & 12 & $13,2 \%$ & 4,05 & \\
\hline & P6 & 0 & $0,0 \%$ & 0 & $0,0 \%$ & 7 & $7,7 \%$ & 18 & $19,8 \%$ & 66 & $72,5 \%$ & 4,65 & \\
\hline \multirow{3}{*}{$\begin{array}{c}\text { Pembentukan } \\
\text { Sikap (X13) }\end{array}$} & P7 & 0 & $0,0 \%$ & 0 & $0,0 \%$ & 13 & $14,3 \%$ & 51 & $56,0 \%$ & 27 & $29,7 \%$ & 4,15 & \multirow{3}{*}{$\begin{array}{l}4, \\
31\end{array}$} \\
\hline & P8 & 0 & $0,0 \%$ & 0 & $0,0 \%$ & 7 & $7,7 \%$ & 32 & $35,2 \%$ & 52 & $57,1 \%$ & 4,49 & \\
\hline & P9 & 0 & $0,0 \%$ & 0 & $0,0 \%$ & 7 & $7,7 \%$ & 51 & $56,0 \%$ & 33 & $36,3 \%$ & 4,29 & \\
\hline \multirow{3}{*}{$\begin{array}{l}\text { Memiliki } \\
\text { Keterampilan } \\
\text { Yang Sesuai } \\
\text { Dengan } \\
\text { Bidangnya } \\
\text { (X14) }\end{array}$} & P10 & 0 & $0,0 \%$ & 0 & $0,0 \%$ & 18 & $19,8 \%$ & 26 & $28,6 \%$ & 47 & $51,6 \%$ & 4,32 & \multirow{3}{*}{$\begin{array}{l}4, \\
42\end{array}$} \\
\hline & $\mathrm{P} 11$ & 0 & $0,0 \%$ & 0 & $0,0 \%$ & 0 & $0,0 \%$ & 44 & $48,4 \%$ & 47 & $51,6 \%$ & 4,52 & \\
\hline & $\mathrm{P} 12$ & 0 & $0,0 \%$ & 0 & $0,0 \%$ & 7 & $7,7 \%$ & 38 & $41,8 \%$ & 46 & $50,5 \%$ & 4,43 & \\
\hline \multicolumn{2}{|l|}{ Rerata Persentase } & - & $0,0 \%$ & 0 & $0,2 \%$ & 10 & $11,1 \%$ & 41 & $38,8 \%$ & 40 & $43,7 \%$ & \multirow{2}{*}{\multicolumn{2}{|c|}{4,28}} \\
\hline \multicolumn{12}{|c|}{ Rerata Variabel Prakerin (X1) } & & \\
\hline
\end{tabular}

Sumber : Data di olah tahun 2019

Tabel 5.1. menunjukkan bahwa nilai rerata variabel prakerin sebesar 4,28. Hal tersebut menunjukkan bahwa sebagian besar siswa teknik Komputer dan Jaringan SMK Telkom Kendari menilai Praktik Kerja Industri yang dicerminkan melalui pemantapan hasil belajar, pengenalan lingkungan, pembentukan sikap siswa serta keterampilan yang sesuai dengan bidangnya sudah dinilai baik. 
Deskripsi Variabel Penelitian Motivasi (X2)

Hasil deskripsi variabel Motivasi dapat dilihat pada tabel 5.2. berikut :

Tabel 5.2. Deskripsi Responden Variabel Motivasi (X2)

\begin{tabular}{|c|c|c|c|c|c|c|c|c|c|c|c|c|c|}
\hline \multirow{3}{*}{$\begin{array}{l}\text { Indikator } \\
\text { Variabel }\end{array}$} & \multirow{3}{*}{ Item } & \multicolumn{10}{|c|}{ Frekwensi (f) dan Persentase (\%) } & \multirow{2}{*}{\multicolumn{2}{|c|}{$\begin{array}{l}\text { Rerata } \\
\text { (Mean) }\end{array}$}} \\
\hline & & \multicolumn{2}{|c|}{ STS (1) } & \multicolumn{2}{|c|}{ TS (2) } & \multicolumn{2}{|c|}{$\mathrm{N}(3)$} & \multicolumn{2}{|c|}{$S(4)$} & \multicolumn{2}{|c|}{ SS (5) } & & \\
\hline & & $\mathrm{F}$ & $\%$ & $\mathrm{f}$ & $\%$ & $\mathrm{~F}$ & $\%$ & $\mathrm{~F}$ & $\%$ & $\mathrm{f}$ & $\%$ & $\begin{array}{c}\text { Ite } \\
\mathrm{m}\end{array}$ & indikator \\
\hline \multirow{2}{*}{$\begin{array}{l}\text { Keinginan dan } \\
\text { Minat (X21) }\end{array}$} & $\mathrm{P} 13$ & 0 & $0,0 \%$ & 6 & $6,6 \%$ & 32 & $35,2 \%$ & 13 & $14,3 \%$ & $\begin{array}{l}4 \\
0 \\
\end{array}$ & $44,0 \%$ & 3,96 & \multirow{2}{*}{4,01} \\
\hline & $\mathrm{P} 14$ & 0 & $0,0 \%$ & 0 & $0,0 \%$ & 20 & $22,0 \%$ & 46 & $50,5 \%$ & $\begin{array}{l}2 \\
5 \\
\end{array}$ & $27,5 \%$ & 4,05 & \\
\hline \multirow{2}{*}{ Kemauan (X22) } & $\mathrm{P} 15$ & 0 & $0,0 \%$ & 0 & $0,0 \%$ & 7 & $7,7 \%$ & 7 & $7,7 \%$ & $\begin{array}{l}7 \\
7 \\
\end{array}$ & $84,6 \%$ & 4,77 & \multirow[t]{2}{*}{4,18} \\
\hline & $\mathrm{P} 16$ & 0 & $0,0 \%$ & 7 & $7,7 \%$ & 31 & $34,1 \%$ & 46 & $50,5 \%$ & 7 & $7,7 \%$ & 3,58 & \\
\hline \multirow{2}{*}{$\begin{array}{l}\text { Desakan dan } \\
\text { Dorongan } \\
\text { Lingkungan } \\
(\mathrm{X} 23) \\
\end{array}$} & $\mathrm{P} 17$ & 6 & $6,6 \%$ & 6 & $6,6 \%$ & 46 & $50,5 \%$ & 26 & $28,6 \%$ & 7 & $7,7 \%$ & 3,24 & \multirow{2}{*}{3,17} \\
\hline & P18 & 6 & $6,6 \%$ & 12 & $13,2 \%$ & 40 & $44,0 \%$ & 33 & $36,3 \%$ & 0 & $0,0 \%$ & 3,10 & \\
\hline \multirow{2}{*}{$\begin{array}{c}\text { Kebutuhan } \\
\text { Fiskologis (X24) }\end{array}$} & P19 & 0 & $0,0 \%$ & 0 & $0,0 \%$ & 25 & $27,5 \%$ & 46 & $50,5 \%$ & $\begin{array}{l}2 \\
0 \\
\end{array}$ & $22,0 \%$ & 3,95 & \multirow{2}{*}{4,29} \\
\hline & $\mathrm{P} 20$ & 0 & $0,0 \%$ & 0 & $0,0 \%$ & 0 & $0,0 \%$ & 33 & $36,3 \%$ & $\begin{array}{l}5 \\
8 \\
\end{array}$ & $63,7 \%$ & 4,64 & \\
\hline \multirow{2}{*}{$\begin{array}{l}\text { Tanggung Jawab } \\
(\mathrm{X} 25)\end{array}$} & P21 & 0 & $0,0 \%$ & 0 & $0,0 \%$ & 13 & $14,3 \%$ & 7 & $7,7 \%$ & $\begin{array}{l}7 \\
1\end{array}$ & $78,0 \%$ & 4,64 & \multirow{2}{*}{4,59} \\
\hline & $\mathrm{P} 22$ & 0 & $0,0 \%$ & 0 & $0,0 \%$ & 0 & $0,0 \%$ & 41 & $45,1 \%$ & $\begin{array}{l}5 \\
0 \\
\end{array}$ & $54,9 \%$ & 4,55 & \\
\hline \multicolumn{2}{|c|}{ Rerata Persentase } & 2 & $1,6 \%$ & 2 & $1,6 \%$ & 13 & $14,4 \%$ & 21 & $22,8 \%$ & $\begin{array}{l}3 \\
1\end{array}$ & $34,5 \%$ & & \multirow{2}{*}{4,05} \\
\hline \multicolumn{12}{|c|}{ Rerata Variabel Motivasi (X2) } & & \\
\hline
\end{tabular}

Sumber : Data di olah tahun 2019

Tabel 5.2. menunjukkan bahwa nilai rerata variabel Motivasi 4.05. Hal tersebut menunjukkan bahwa sebagian besar siswa teknik Komputer dan Jaringan SMK Telkom Kendari menilai Motivasi yang dicerminkan melalui keinginan dan minat, kemauan, desakan dan dorongan lingkungan, kebutuhan psikologis dan tanggung jawab sudah dinilai baik. 
Deskripsi Variabel Kesiapan Kerja (Y)

Hasil deskripsi variabel Kesiapan Kerja dapat dilihat pada tabel 5.3. berikut :

Tabel 5.3. Deskripsi Responden Variabel Kesiapan Kerja

\begin{tabular}{|c|c|c|c|c|c|c|c|c|c|c|c|c|c|}
\hline \multirow{3}{*}{$\begin{array}{l}\text { Indikator } \\
\text { Variabel }\end{array}$} & \multirow{3}{*}{ Item } & \multicolumn{10}{|c|}{ Frekwensi (f) dan Persentase (\%) } & \multirow{2}{*}{\multicolumn{2}{|c|}{$\begin{array}{l}\text { Rerata } \\
\text { (Mean) }\end{array}$}} \\
\hline & & \multicolumn{2}{|c|}{ STS (1) } & \multicolumn{2}{|c|}{ TS (2) } & \multicolumn{2}{|c|}{$\mathrm{N}(3)$} & \multicolumn{2}{|c|}{$S(4)$} & \multicolumn{2}{|c|}{ SS (5) } & & \\
\hline & & $\mathrm{F}$ & $\%$ & $\mathrm{f}$ & $\%$ & $\mathrm{~F}$ & $\%$ & $\mathrm{~F}$ & $\%$ & $\mathrm{~F}$ & $\%$ & Item & indikator \\
\hline \multirow{3}{*}{$\begin{array}{c}\text { Memiliki } \\
\text { Pertimbangan } \\
\text { Obyektif (Y11) }\end{array}$} & $\mathrm{P} 23$ & 0 & $\begin{array}{c}0,0 \\
\%\end{array}$ & 0 & $0,0 \%$ & 0 & $0,0 \%$ & 45 & $\begin{array}{c}49,5 \\
\%\end{array}$ & 46 & $50,5 \%$ & 4,51 & \multirow{3}{*}{3,71} \\
\hline & $\mathrm{P} 24$ & 0 & $\begin{array}{c}0,0 \\
\%\end{array}$ & 32 & $35,2 \%$ & 52 & $57,1 \%$ & 7 & $7,7 \%$ & 0 & $0,0 \%$ & 2,73 & \\
\hline & $\mathrm{P} 25$ & 0 & $\begin{array}{c}0,0 \\
\%\end{array}$ & 7 & $7,7 \%$ & 7 & $7,7 \%$ & 65 & $\begin{array}{c}71,4 \\
\%\end{array}$ & 12 & $13,2 \%$ & 3,90 & \\
\hline \multirow{2}{*}{$\begin{array}{c}\text { Sikap } \\
\text { Kritis (Y12) }\end{array}$} & P26 & 0 & $\begin{array}{c}0,0 \\
\%\end{array}$ & 7 & $7,7 \%$ & 0 & $0,0 \%$ & 40 & $\begin{array}{c}44,0 \\
\%\end{array}$ & 44 & $48,4 \%$ & 4,33 & \multirow{2}{*}{4,48} \\
\hline & $\mathrm{P} 27$ & 0 & $\begin{array}{c}0,0 \\
\%\end{array}$ & 0 & $0,0 \%$ & 0 & $0,0 \%$ & 33 & $\begin{array}{c}36,3 \\
\%\end{array}$ & 58 & $63,7 \%$ & 4,64 & \\
\hline \multirow{2}{*}{$\begin{array}{c}\text { Pengendalian } \\
\text { Emosional (Y13) }\end{array}$} & P28 & 0 & $\begin{array}{c}0,0 \\
\%\end{array}$ & 0 & $0,0 \%$ & 0 & $0,0 \%$ & 60 & $\begin{array}{c}65,9 \\
\% \\
\end{array}$ & 31 & $34,1 \%$ & 4,34 & \multirow{2}{*}{4,35} \\
\hline & P29 & 0 & $\begin{array}{c}0,0 \\
\%\end{array}$ & 0 & $0,0 \%$ & 0 & $0,0 \%$ & 59 & $\begin{array}{c}64,8 \\
\% \\
\end{array}$ & 32 & $35,2 \%$ & 4,35 & \\
\hline \multirow{3}{*}{$\begin{array}{c}\text { Kemampuan } \\
\text { Beradaptasi } \\
\text { dengan } \\
\text { Lingkungan (Y14) }\end{array}$} & $\mathrm{P} 30$ & 6 & $\begin{array}{l}6,6 \\
\%\end{array}$ & 40 & $44,0 \%$ & 44 & $48,4 \%$ & 0 & $0,0 \%$ & 1 & $1,1 \%$ & 2,45 & \multirow{3}{*}{3,63} \\
\hline & P31 & 0 & $\begin{array}{c}0,0 \\
\%\end{array}$ & 0 & $0,0 \%$ & 13 & $14,3 \%$ & 58 & $\begin{array}{c}63,7 \\
\%\end{array}$ & 20 & $22,0 \%$ & 4,08 & \\
\hline & P32 & 0 & $\begin{array}{c}0,0 \\
\%\end{array}$ & 0 & $0,0 \%$ & 6 & $6,6 \%$ & 46 & $\begin{array}{c}50,5 \\
\%\end{array}$ & 39 & $42,9 \%$ & 4,36 & \\
\hline \multirow{3}{*}{$\begin{array}{l}\text { Bertanggung } \\
\text { Jawab (Y15) }\end{array}$} & P33 & 0 & $\begin{array}{c}0,0 \\
\%\end{array}$ & 0 & $0,0 \%$ & 0 & $0,0 \%$ & 47 & $\begin{array}{c}51,6 \\
\%\end{array}$ & 44 & $48,4 \%$ & 4,48 & \multirow{3}{*}{4,45} \\
\hline & P34 & 0 & $\begin{array}{c}0,0 \\
\%\end{array}$ & 0 & $0,0 \%$ & 0 & $0,0 \%$ & 45 & $\begin{array}{c}49,5 \\
\%\end{array}$ & 46 & $50,5 \%$ & 4,51 & \\
\hline & P35 & 0 & $\begin{array}{c}0,0 \\
\%\end{array}$ & 0 & $0,0 \%$ & 0 & $0,0 \%$ & 59 & $\begin{array}{c}64,8 \\
\%\end{array}$ & 32 & $35,2 \%$ & 4,35 & \\
\hline \multirow{2}{*}{$\begin{array}{l}\text { Mempunyai } \\
\text { Ambisi Untuk } \\
\text { Maju (Y16) }\end{array}$} & P36 & 0 & $\begin{array}{c}0,0 \\
\%\end{array}$ & 0 & $0,0 \%$ & 13 & $14,3 \%$ & 59 & $\begin{array}{c}64,8 \\
\% \\
\end{array}$ & 19 & $20,9 \%$ & 4,07 & \multirow{2}{*}{4,10} \\
\hline & P37 & 0 & $\begin{array}{c}0,0 \\
\%\end{array}$ & 7 & $7,7 \%$ & 0 & $0,0 \%$ & 58 & $\begin{array}{c}63,7 \\
\% \\
\end{array}$ & 26 & $28,6 \%$ & 4,13 & \\
\hline \multirow{3}{*}{$\begin{array}{l}\text { KemauanBekerja } \\
\text { Sama dengan } \\
\text { Orang Lain (Y17) }\end{array}$} & P38 & 7 & $\begin{array}{c}7,7 \\
\%\end{array}$ & 0 & $0,0 \%$ & 7 & $7,7 \%$ & 58 & $\begin{array}{c}63,7 \\
\%\end{array}$ & 19 & $20,9 \%$ & 3,90 & \multirow{3}{*}{3,71} \\
\hline & P39 & 0 & $\begin{array}{c}0,0 \\
\%\end{array}$ & 7 & $7,7 \%$ & 0 & $0,0 \%$ & 45 & $\begin{array}{c}49,5 \\
\%\end{array}$ & 39 & $42,9 \%$ & 4,27 & \\
\hline & $\mathrm{P} 40$ & 8 & $\begin{array}{c}8,8 \\
\%\end{array}$ & 23 & $25,3 \%$ & 31 & $34,1 \%$ & 22 & $\begin{array}{c}24,2 \\
\%\end{array}$ & 7 & $7,7 \%$ & 2,97 & \\
\hline \multicolumn{2}{|c|}{ Rerata Persentase } & - & $\begin{array}{c}0,0 \\
\% \\
\end{array}$ & - & $0,0 \%$ & 8 & $8,9 \%$ & 33 & $\begin{array}{c}36,1 \\
\% \\
\end{array}$ & 50 & $54,9 \%$ & & 4,10 \\
\hline
\end{tabular}

Sumber : Data di olah tahun 2019

Tabel 5.3. menunjukkan bahwa nilai rerata variabel kesiapan Kerja 4.10. Hal tersebut menunjukkan bahwa sebagian besar siswa teknik Komputer dan Jaringan SMK Telkom Kendari menilai Kesiapan Kerja yang dicerminkan melalui Pertimbangan yang obyektif, Sikap kritis, kemampuan beradaptasi dengan 
lingkungan, bertanggung jawab, mempunyai ambisi untuk maju dan kemampuan bekerja sama dengan orang lain sudah dinilai baik.

Tabel 5.4. Rekapitulasi Hasil Uji Validitas dan Reliabilitas Instrumen

\begin{tabular}{|c|c|c|c|c|c|c|c|}
\hline $\begin{array}{l}\text { Variabel } \\
\text { Penelitian }\end{array}$ & $\begin{array}{l}\text { Indikator } \\
\text { Penelitian }\end{array}$ & $\begin{array}{l}\text { Item/ } \\
\text { Butir }\end{array}$ & $\begin{array}{c}\text { Koefisie } \\
n \\
\text { Korelasi } \\
(\mathrm{r})\end{array}$ & $\begin{array}{l}\text { Signi } \\
\text { Fikansi }\end{array}$ & Hasil & $\begin{array}{c}\text { Cronbac } \\
\text { h's } \\
\text { Alpha }\end{array}$ & Hasil \\
\hline$(1)$ & $(2)$ & (3) & $(4)$ & $(5)$ & $(6)$ & $(7)$ & $(8)$ \\
\hline \multirow{4}{*}{$\begin{array}{c}\text { Pengalaman } \\
\text { Prakerin } \\
\text { (X1) }\end{array}$} & Pemantapan Hasil Belajar & $(\mathrm{X} 11)$ & 0,340 & 0,066 & Valid & \multirow{4}{*}{0,790} & \multirow{4}{*}{$\begin{array}{c}\text { Reliabe } \\
1\end{array}$} \\
\hline & Pengenalan Lingkungan & $(\mathrm{X} 12)$ & 0,532 & 0,002 & Valid & & \\
\hline & Pembentukan Sikap & $(\mathrm{X} 13)$ & 0,916 & 0,000 & Valid & & \\
\hline & $\begin{array}{l}\text { Memiliki Keterampilan Sesuai } \\
\text { Bidang }\end{array}$ & (X14) & 0,665 & 0,000 & Valid & & \\
\hline \multirow{5}{*}{$\begin{array}{l}\text { Motivasi } \\
\text { (X2) }\end{array}$} & Keinginan dan Minat & $(\mathrm{X} 21)$ & 0,439 & 0,015 & Valid & \multirow{5}{*}{0,637} & \multirow{5}{*}{$\begin{array}{c}\text { Reliabe } \\
1\end{array}$} \\
\hline & Kemauan & $(\mathrm{X} 22)$ & 0,674 & 0,000 & Valid & & \\
\hline & Desakan dan Dorongan Lingkungan & $(\mathrm{X} 23)$ & 0,394 & 0,015 & Valid & & \\
\hline & Kebutuhan Fisiologi & (X24) & 0,494 & 0,006 & Valid & & \\
\hline & Tanggung Jawab & $(\mathrm{X} 25)$ & 0,384 & 0,036 & Valid & & \\
\hline \multirow{7}{*}{$\begin{array}{l}\text { Kesiapan } \\
\text { Kerja (Y) }\end{array}$} & Perasaan Bangga & $(\mathrm{Y} 1)$ & 0,474 & 0,008 & Valid & \multirow{7}{*}{0,614} & \multirow{7}{*}{$\begin{array}{c}\text { Reliabe } \\
1\end{array}$} \\
\hline & Rasa Memiliki & $(\mathrm{Y} 2)$ & 0,448 & 0,013 & Valid & & \\
\hline & Keinginan Menjalin Hubungan & (Y3) & 0,456 & 0,011 & Valid & & \\
\hline & Melakukan Pembelian Ulang & (Y4) & 0,545 & 0,002 & Valid & & \\
\hline & Merekemendasikan Perusahaan & (Y5) & 0,398 & 0,010 & Valid & & \\
\hline & Membeli Di Luar Lini Produk Jasa & (Y6) & 0,400 & 0,028 & Valid & & \\
\hline & $\begin{array}{l}\text { Tidak Canggung Menyampaikan } \\
\text { Komplain }\end{array}$ & (Y7) & 0,725 & 0,000 & Valid & & \\
\hline
\end{tabular}

Dari hasil rekapitulasi uji validitas dan reliabilitas instrumen pada Tabel 5.4 menunjukkan bahwa seluruh variabel penelitian adalah valid karena koefisien korelasi semua indikatornya lebih besar dari 0,30 dan cronbach alpha lebih besar dari 0,60 yang berarti semua item pernyataan yang dijadikan sebagai instrumen dapat dipercaya keabsahannya. Dengan demikian, dapat disimpulkan bahwa seluruh butir pernyataan yang digunakan untuk pengukuran variabel-variabel yang dianalisis dalam penelitian ini yakni: Pengalaman Prakerin, Motivasi dan Kesiapan Kerja, adalah valid dan reliabel. Dengan demikian instrumen atau kuesioner yang digunakan dapat dikatakan valid dan dipercaya serta memiliki tingkat keabsahan yang dapat diterima sebagai instrumen untuk melakukan pengukuran setiap indikator dan analisis data selanjutnya.

\section{Uji Normalitas}

Pengujian distribusi normal (uji normalitas) menggunakan normal probability plot. Tujuan uji normalitas adalah ingin mengetahui apakah distribusi sebuah data mengikuti atau mendekati distribusi normal. Data yang baik adalah 
data yang mempunyai pola seperti distribusi normal, yakni terdapat disekitar garis uji yang mengarah kekanan atas, dan tidak ada data yang terletak jauh dari sebaran data, maka dengan demikian data tersebut dikatakan normal (Santoso, 2000). Hasil Uji Normalitas disajikan pada gambar berikut :

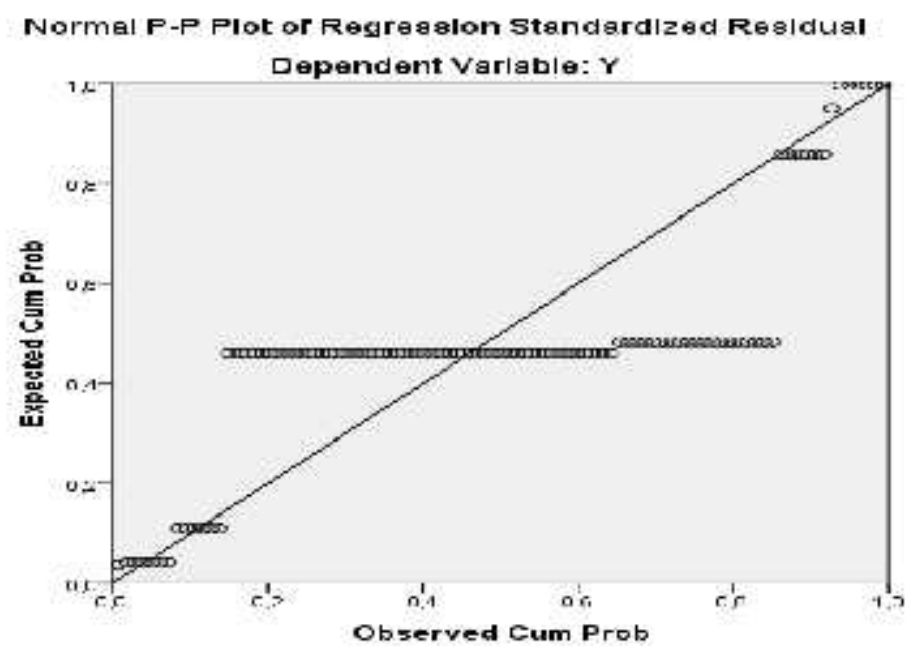

Gambar 5.1. Hasil Uji Normalitas

Dari hasil analisis pada Gambar 5.1. Gambar normal P-P Plot terlihat bahwa disekitar garis uji mengarah kekanan atas tidak ada data yang terletak jauh dari sebaran data dengan demikian dapat disimpulkan bahwa data terdistribusi normal.

\section{Hasil Analisis Data}

Dari hasil analisis dengan Regresi Linear Berganda terhadap 3 (tiga) variabel yang diteliti yakni pengalaman Praktik kerja industri (prakerin), motivasi dan kesiapan kerja siswa, maka hasil analisis dapat dilihat pada tabel 5.6 .

Tabel 5.6. Hasil Ringkasan Regresi Linear Berganda

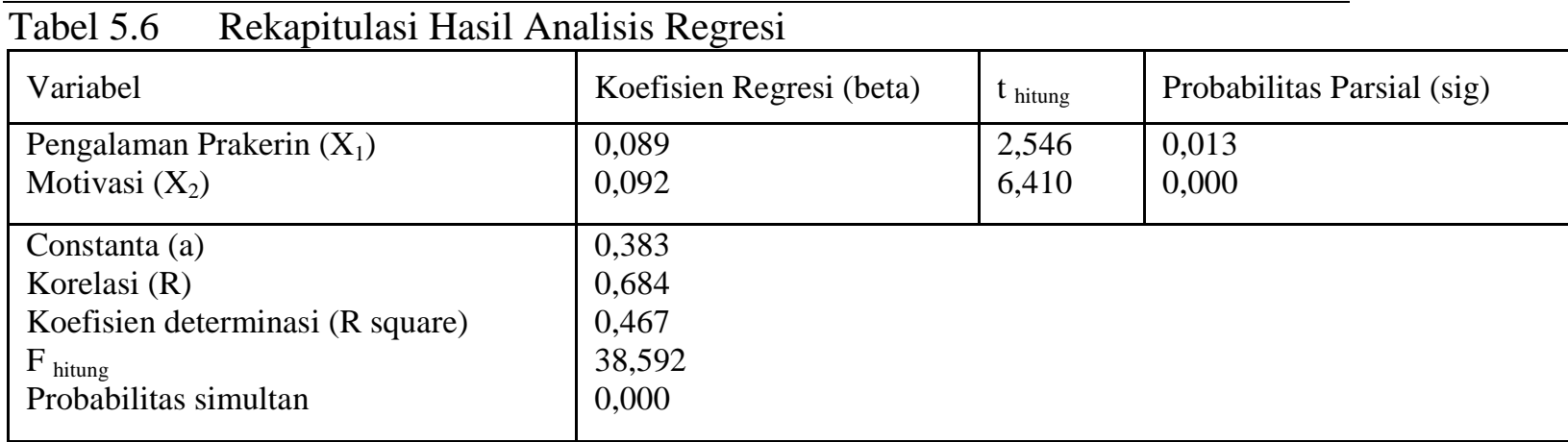

Sumber : Data diolah, 2019 


\section{a. Persamaan Regresi}

Tabel 5.6 di atas, maka persamaan garis regresi linear berganda yang dicari dapat di ketahui yaitu :

\section{b. Koefisien Regresi}

$$
\begin{aligned}
& Y=a+b_{1} X_{1}+b_{2} X_{2} \\
& Y=0,383+0,089, X_{1}+0,092 X_{2}
\end{aligned}
$$

Dimaksudkan untuk mengetahui besarnya pengaruh pengalaman praktik kerja industri dan motivasi terhadap kesiapan kerja siswa. Sesuai dengan data pada tabel 5.6 diketahui bahwa :

Persamaan di atas mengandung makna sebagai berikut :

$\mathrm{a}=0,383$, artinya bahwa nilai kesiapan kerja siswa SMK Telkom Kendari sebelum dipengaruhi oleh pengalaman prakerin dan motivasi apabila diukur dengan menggunakan skala Likert sebesar 0,383.

p1 = 0,089, artinya bahwa apabila pengalaman praktik kerja industri meningkat maka kesiapan kerja siswa akan semakin meningkat sebesar 0,089 dengan asumsi faktor lain (motivasi) konstan.

p $2=0,092$, artinya bahwa apabila motivasi ditingkatkan, maka kesiapan kerja siswa akan meningkat sebesar 0,092 dengan asumsi variabel lain (pengalaman prakerin) konstan.

\section{c. Koefisien Korelasi (r)}

Hasil analisis koefisien Korelasi (R) menyatakan bahwa besarnya koefisien Korelasi $(\mathrm{R})$ yang diperoleh sebesar 0,684. Hasil tersebut berarti bahwa pengalaman praktik kerja industri dan motivasi berhubungan positif dan kuat dalam upaya peningkatan kesiapan kerja siswa SMK Telkom Kendari. Artinya apabila pengalaman praktik industri dan motivasi siswa SMK Telkom Kendari ditingkatkan maka kesiapan kerja siswa akan semakin meningkat.

\section{PEMBAHASAN HASIL}

\section{Pengaruh Pengalaman Praktik Kerja Industri (Prakerin) dan Motivasi terhadap Kesiapan Kerja Siswa}

Berdasarkan hasil pengujian pengaruh simultan pengalaman praktik kerja industri (prakerin) dan motivasi terhadap kesiapan kerja. Menemukan bahwa peningkatan pengalaman praktik kerja industri (prakerin) dan motivasi berpengaruh positif dan signifikan terhadap kesiapan kerja siswa SMK Telkom Kendari. Hasil pengujian ini dapat diartikan bahwa adanya kecenderungan perubahan peningkatan pengalaman praktik kerja industri (prakerin) yang tinggi dan motivasi secara besama-sama berpengaruh signifikan terhadap kesiapan kerja. Oleh karena itu, tingginya pengalaman praktik kerja industri (prakerin) yang didukung oleh peningkatan motivasi dapat pula meningkatkan kesiapan kerja.

Terciptanya pengalaman praktik kerja industri (prakerin) dan motivasi yang tinggi akan menyebabkan para siswa selalu menepati jam masuk kantor dan menepati jam pulang kantor. Hal ini dapat dibuktikan dengan tingginya antusias siswa mengikuti apel pagi dan mengisi absen pulang. Selain itu siswa selalu mengusahakan untuk tidak menggunakan peralatan kerja secara boros dan selalu memelihara dan menjaga baik hal hal yang dihasilkan di lingkup unit kerja. Kemampuan siswa melakukan pekerjaannya dengan teliti dan menjaga kesesuaian 
penampilan pada saat berada ditempat kerja sehingga lebih profesional. Pengalaman praktik kerja industri akan mempengaruhi peserta didik untuk membuat pertimbangan yang logis, mempunyai kemampuan dan kemauan untuk bekerja sama dengan orang lain. Mampu mengendalikan diri atau emosi, memiliki sikap kritis, mempunyai kemampuan beradaptasi dengan lingkungan atau perkembangan teknologi, dan mempunyai ambisi untuk maju serta berusaha mengikuti perkembangan bidang keahlian. Semakin banyak pengalaman praktik kerja industri akan menyebabkan kesiapan kerja peserta didik menjadi tinggi dan sebaliknya, semakin sedikit pengalaman praktik kerja industri akan menyebabkan kesiapan kerja peserta didik menjadi rendah.

Hasil analisis regresi dapat dijelaskan bahwa peningkatan pengalaman praktik kerja industri (prakerin) dan motivasi siswa SMK Telkom Kendari, menyebabkan siswa menjadi kritis, memiliki sikap untuk mengendalikan emosi, mampu beradaptasi dengan lingkungan, bertanggungjawab, serta mempunyai ambisi untuk maju. dalam penelitian ini menemukan bahwa peningkatan motivasi yang semakin baik akan berdampak terhadap kesiapan kerja yang semakin baik. Dari Hasil deskripsi variabel motivasi bahwa dari 5 indikator motivasi, indikator yang dipersepsikan paling baik adalah tanggung jawab, artinya bahwa para siswa mampu memotivasi dirinya untuk memilih bekerja dari pada menganggur dan kemudian siswa juga merasa lebih mulia dan terpandang baik dimata masyarakat jika bekerja dari pada menganggur.

Sehubungan dengan itu, hasil penelitian ini sejalan dengan penelitian yang dilakukan oleh Yanuar Mipalas, et.al (2012) bahwa pengalaman raktek kerja industri dan motivasi berpengaruh positif dan sigifikan terhadap kesiapan kerja siswa.

\section{Pengaruh Pengalaman Praktik Kerja Industri (Prakerin) terhadap Kesiapan Kerja Siswa}

Dari hasil pengujian hipotesis kedua bahwa pengalaman praktik kerja industri (prakerin) berpengaruh positif dan signifikan terhadap kesiapan kerja siswa SMK Telkom Kendari menemukan bahwa pengalaman praktik kerja industri (prakerin) berpengaruh positif dan signfikan terhadap kesiapan kerja. Hal ini dapat dimaknai bahwa peningkatan pengalaman praktik kerja industri (prakerin) mampu membawa perubahan besar pada kesiapan kerja.

Model pengukuran hubungan kausal antara konstruk atau variabel pengalaman praktik kerja industri (prakerin), motivasi dan kesiapan kerja yang diajukkan pada model regresi selanjutnya diinterpertasikan dengan menjelaskan hubungan kausal antara konstruk atau variabel.

\section{Pengaruh Motivasi Terhadap Kesiapan Kerja Siswa}

Berdasarkan hasil uji hipotesis ketiga bahwa motivasi berpengaruh positif dan signifikan terhadap kesiapan kerja menemukan bahwa semakin baik motivasi dalam lingkup SMK Telkom Kendari, maka kesiapan kerja juga akan semakin baik. Di samping itu, dari hasil deskripsi siswa menemukan bahwa aspek yang paling dominan dalam berkontribusi terhadap motivasi adalah sikap bertanggung 
jawab siswa yang dicerminkan melalui keinginan kuat untuk memperoleh pekerjaan ketimbang menganggur.

\section{PENUTUP}

\section{Kesimpulan}

Berdasarkan hasil analisis dan pembahasan pada uraian sebelumnya, maka dapat disimpulkan hal-hal sebagai berikut :

1. Pengalaman Praktik kerja industri (Prakerin) dan Motivasi Secara Simultan Berpengaruh Positif dan signifikan Terhadap kesiapan Kerja Siswa Kelas XII Program Keahlian Teknik Komputer dan Jaringan.

2. Pengalaman Praktik kerja industri berpengaruh positif dan signifikan terhadap kesiapan kerja siswa kelas XII program keahlian teknik Komputer dan Jaringan SMK Telkom Kendari.

3. Motivasi berpengaruh positif dan signifikan terhadap kesiapan kerja siswa kelas XII program keahlian teknik Komputer dan Jaringan SMK Telkom Kendari.

\section{Saran}

1. Pihak Sekolah agar menggunakan referensi yang Uptodate sehingga mampu mengatasi kesenjangan antara materi-materi dan teori pada saat melakukan praktikum. Selain itu perlunya dilengkapi fasilitas prakerin dan jumlah peralatan sehingga siswa bisa melaksanakan prakerin tanpa harus menunggu lama untuk melaksanakannya.

2. Pentingnya pengaruh kerjasama dengan industri otomotoif sehingga siswa dapat menambah pengalaman lebih banyak pada industri-industri skala nasional.

3. Berdasarakan penilaian indikator yang ke lima menunjukkan bahwa desakan dan dorongan lingkungan merupakan indikator yang dirasakan oleh siswa sebagian kecil belum optimal dengan nilai rerata 3.17. Hal ini menunjukan bahwa kurangnya motivasi dari orang tua untuk mendorong anaknya dalam melamar pekerjaan.

\section{DAFTAR PUSTAKA}

Dalyono, M. 2005. Psikologi Pendidikan. Jakarta: Rhineka Cipta.

Depdikbud. 1997. Penyusunan Kurikulum Pendidikan Sistem Ganda. Jakarta: Depdikbud.

Depdiknas. 2006. Pedoman Pelaksanaan Praktek Kerja Industri (SMK). Jakarta: DPMK.

Herminanto, Sofyan. 1986. "Kesiapan Kerja STM Se-Jawa untuk memasuki Lapangan Kerja”. Yogyakarta: Jurnal Pendidikan Lembaga Penelitian IKIP Yogyakarta.

Kartini, Kartono. 1991. Menyiapkan dan Memandu Karier. Jakarta: Rajawali Pers. Ngalim, Purwanto. 1998. Psikologi Pendidikan. Bandung: Remaja Rosdakarya.

Martin, Handoko. 1992. Motivasi Daya Penggerak Tingkah Laku. Yogyakarta: Kanisius. 
Moh, Thayep Manribu. 1998. Pengantar Bimbingan dan Konseling Karir. Jakarta: Depdikbud.

Oemar, Hamalik. 2008. Proses Belajar Mengajar. Jakarta: Bumi Aksara.

Rupert, Evans. 1978. Tujuan Pendidikan. Bandung: Pustaka Insan Madani.

Santoso, Singgih. 2000. Buku Latihan SPSS: Statistik Parametrik. Jakarta: Elex Media Komputindo.

Siagian, P. Sondang. 2003. Manajemen Sumber Daya Manusia. Jakarta: Bumi Aksara.

Schippers, Uwe. 1996. Pendidikan Kejuruan di Indonesia. Bandung: Angkasa.

Sugiyono. 2008. Metode Penelitian Kuantitatif Kualitatif da $R$ dan D. Alfabeta: Bandung.

Slameto. 2010. Belajar dan Faktor-faktor yang Mempengaruhi. Jakarta: Rineka Cipta.

Wardiman, Djojonegoro. 2007. Pengembangan Sumber Daya manusia Melalui Pendidikan dan Kebudayaan. Jakarta: PT Jayakarta Agung Offset

Wena. 2009. Pendidikan Sistem Ganda. Bandung: Tarsito

Yanuar Mipalas Valid, Abdullah Taman. 2012. "Pengaruh Pengalaman Praktik Industri Dan Motivasi Terhadap Kesiapan Kerja Siswa Kelas XII Program Keahlian Akuntansi Smk Ypkk 2 Sleman Yogyakarta”. Yogyakarta: SMK YPKK 2 Sleman.

Referensi internet :

http://psmk.kemdikbud.go.id/konten/1869/konsep-pembelajaran-di-sekolahmenengah-kejuruan. Diakses pada tanggal 29 Agustus 2019. 